\title{
Exploring the Effect of Job Satisfaction on Organizational Commitment of the University Teachers
}

\author{
Pragalbh Sharma, Aparna Raj
}

\begin{abstract}
The aim of this research work is to learn about teacher's attitude towards the educational institutions. This research work will evaluate two factors related to organizational/professional commitment of University teachers in Mathura District. The population for this study includes the samples of 150 teachers, teaching in the university systems who are the respondents utilized to determine these two factors Job-satisfaction and Self-efficacy, the components of Job-commitment. In order to identify the variables, the systematic random sampling method was undertaken to select the sample for this study. A well structured questionnaire was used by the researcher to conduct the survey, which was devised after taking the references from a variety of related studies conducted by different researchers in past. A comprehensive 'Reliability-analysis' was performed along with correlation, and regression analysis in SPSS. The result thus obtained indicates a noteworthy connection between the work satisfaction and commitment of the university teachers, which strengthened the hypothesis that the increase in work satisfaction tends to increase the commitment of the university teachers towards their organization. It is recommended that teacher's operational environment should be enhanced, and they should be given more incentives and better remuneration package in comparison to previous to enhance their satisfaction..
\end{abstract}

Keywords: Job Satisfaction, Work Commitment, Self Efficacy, University Teachers etc.

\section{INTRODUCTION}

Teacher is a basic constituent of the learning environment who is responsible for different significant tasks and duties. The total performance of the colleges and universities lies on their teachers and eventually the extent of their commitment towards the organization and job contentment. The study of behaviors within a given constraint is harmful for assessing the performance of workforce in any organization. This concept stands correct when we focus on the quality of human capital in the organization which is one of the most important elements that add appreciably towards the growth of an organization. (Pohlman \& Gardiner, 2000).

Revised Manuscript Received on December 12, 2019.

* Correspondence Author

Mr. Pragalbh Sharma*, Assistant Professor, Department of Management, Institute of Business Management, GLA University, Mathura (UP)-India.

Prof. Aparna Raj, Professor, Department of Tourism and Hotel Management in Bundelkhand University, Jhansi (UP)-India.

(c) The Authors. Published by Blue Eyes Intelligence Engineering and Sciences Publication (BEIESP). This is an open access article under the CC BY-NC-ND license (http://creativecommons.org/licenses/by-nc-nd/4.0/)
The current epoch of management is focused on effectual utilization of HR in making foundation for the performance of the organization is considered a significant gauge of winning or defeat. Hence, the worker's or employee's extent of job satisfaction and his commitment for the organization has developed into a subject matter of research for the social researchers. (Taşdan \& Tiryaki, 2008).

A strong and powerful education system is well thought-out as vertebral column for a growing nation and an educator is the spindle reeled along the whole academic system. The growth of a learning organization depends on the superiority and potential of the educators, compulsory to the system and is the motivating strength for societal growth.

Organizational/Satisfaction from the work and enthusiasm to work are significant for the life of the educators since they encompass main motive of working throughout their life. Approximately every teacher work for the satisfaction of his desire by imparting education and moral values.

\subsection{Research Objectives:}

- To analyse the impact of job satisfaction on organisational commitment of teachers.

- To analyse the impact of self efficacy on job satisfaction of teachers.

- To analyse the impact of self efficacy on organisational commitment of teachers.

- To analyse the impact of self efficacy and job satisfaction on organisational commitment of teachers.

1.2. Need and Importance:

- Teachers/Educators working in the university system are looking for the policies which can bring job satisfaction for them and also encourage their professional and institutional commitment.

- It is observed that academic professionals working in the higher education system has shown an increase in the turnover ratio. This aspect affects their dedication for the institution.

- This research will determine linkage between work satisfaction and professional commitment towards organisation in the teachers teaching in the university system, to evaluate their level of commitment and satisfaction from the organisation.

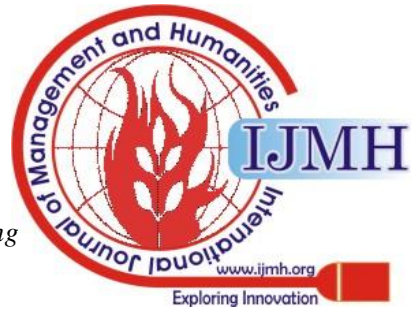




\section{On Associative Meanings of Medicinal Traditional Fruits: A Semantico-Pragmatic Perspective of Local-Cultured Environmental Richness}

- In the recent time no such study related to the current topic has been undertaken therefore, the outcomes of this research work will help the university management in devising polices for the persuasion of dedication and commitment for the organisation in university teachers so that their chances of retention in the organisation may also be improved.

\subsection{Problem Statement:}

- Both, satisfaction and commitment of employees for their organization is extremely important.

- It is a growing challenge for every organization to keep those employees who are dedicated, committed and also support the organization in enhancing its competitiveness.

- It is very essential to observe the impact of satisfaction to improve the dedication and devotion of the teaching professionals for the organisation because, the teaching sector is now being considered as a stressful sector.

\section{REVIEW OF LITERATURE}

\subsection{Job/Work Satisfaction:}

It may be explained as amount or level, a worker experience self-motivation, happiness \& satisfaction with his/her job. There are several components of job satisfaction like job permanence, individual growth and a perfect work life balance which defines the degree of satisfaction of the employees at the workplace. Therefore, the satisfaction level from the job of an employee depends upon how his expectations from these and similar components are met.

- According to Hicks, 2003 a lot of teachers who originally started their career with passion and optimistic outlook looked for an adjustment in the track after 3 to 5 years while qualified and knowledgeable teachers suffering from lack of satisfaction are leaving their profession in order to search for another employment.

- As per the related research study undertaken by Abbasi in 2003, of work satisfaction in the primary school teachers working in Iran and India, an aggregate of more than fifty percent of the teachers have average amount of satisfaction drawn from their jobs in these countries, depicting serious issues related to the condition of teachers in their societies and educational system in both the countries. Those schools where the staffs have very little satisfaction from their jobs are found to be very less blooming and very unsuccessful.

- In the study conducted by Aamodt 2007 and Delaney 2002 give emphasis to job satisfaction which can be established directly to commitment, as the company is likely to provide work to those who have a higher level of dedication for the job. Job disappointment causes small commitment and output.

- Fenot 2005 and Gedefaws's 2012 demonstrated that teacher's job satisfaction is mainly intimately related to features inherent to the task of teaching that is to say, teacher's effectiveness and development.

- Raj and Marry in 2014, also conducted a study on satisfaction of teachers from their job in the
Puducherry region and established that the level of satisfaction level of the teachers in this region was also very low and unsatisfactory.

\subsection{Organizational Commitment:}

This may be explained by the attitude of worker for the organization where he work or his psychological attachment to the organization and the workplace. Organizational commitment plays a very crucial role in deciding that whether or not an employee will continue with the organization for longer time duration and work fervently for the achievement of organizational goals.

- According to a study conducted by, Crossman \& Harris, 2006; suggests that organizational dedication is "a strength that sticks or compels an individual to a significant path of action for the achievement of desired goals".

- According to Day (2000), teacher commitment is multi-dimensional and multi-faceted. A fully dedicated employee is directed towards the success of the organisation to which he belongs and flourishes in the current vibrant context of the modern organisations.

- According to Robbins \& Coulter, 2005, Organizational commitment guide to lower levels of both absenteeism and is a good indicator of turnover as compared to satisfaction.

- In a research conducted by Ayeni and Phopoola, 2007 describes that the employees have a propensity dedicated to a business, and workers contented and dedicated are more prone to present at work, continue in an institution, reach work timely, act upon finely and remain involved in the supportive acts for the organisation.

\subsection{Satisfaction and Organizational Commitment:}

The withholding of particular as well as capable human resources is a substantial issue which is faced by many organizations these days. Number of research studies has already explained the relationship between these two variables related to the employees and also their degree of turnover is viewed as a significant pointer of the satisfaction and dedication of employees and afterward the value and competence of an organization.

- On the basis of the research study undertaken by Ian Howard in (2005), there is no statistical relationship found between these two variables amongst the teachers from underprivileged parts in Western Cape.

- According to research study accomplished by Werner in 2007, only the contented workers show signs of positive behaviour that also affects the overall performance of the organization. $\mathrm{He}$ also demonstrated that female workers have a low commitment as compared to the male workers.

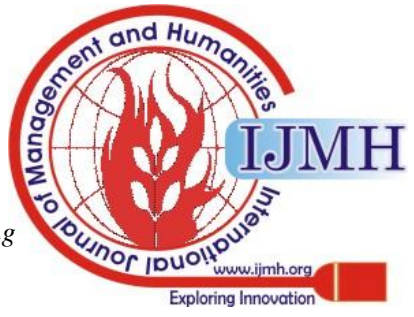


- As per the study conducted by Raza and Nawaz in (2011), it was stated that maximum of the samples of teachers had a very positive commitment towards their organization despite of their level of job satisfaction being less than average.

- Teferi, Bekalu, Abebe and Burichew in (2016) in their study determined an affirmative relationship between these two variables among the teachers of sampled schools. Sex was only demographic variable having a very important relationship with the job satisfaction.

Hence, it is evident,

H1: Job satisfaction effects the organisational commitment.

\subsection{Conceptual Framework:}

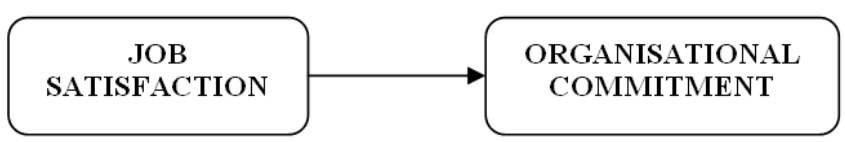

\section{RESEARCH METHODOLOGY}

Research is a careful and detailed study of any particular topic or subject in a systematic and organized way. There are certain things in research process in order to get good results which are always adopt and done by the researcher. Research Methodology refers to a method for research. In this method there are various method and stages which are normally thoroughly assumed by the researchers in learning their research problems along with the sense behind them. It aims to describe and analyze methods by focusing on the limitations, resources and consequences relating to the subject of the research.

This study is based on the exploration of association between these two variables among university teachers, teaching in the universities located in Mathura district and nearby region. The teaching professionals were requested to respond to a set of questions asked through a well structured questionnaire with reference to the working practices that related with their organization. The sample drawn for this study is 150 and the sample population is the academic professionals teaching in university.

In this research report inferential research is used. There are some types of inferential research method which are which are used for this study like Model summary, ANOVA, Coefficients of regression and regression analysis is done based on the responses received through the questionnaire using SPSS.

\section{RESULTS}

H1: There exists a considerable effect of work satisfaction on professional commitment.

Mod. Summary

\begin{tabular}{|l|c|c|r|r|}
\hline Mod. & $\mathrm{R}$ & $\begin{array}{c}\mathrm{R} \\
\text { Sq. }\end{array}$ & Adjst. R Sq. & Std. Error of Estmt. \\
\hline 1 & $.290^{\mathrm{a}}$ & .084 & .083 & 4.98454 \\
\hline
\end{tabular}

a. Predict: (Const.), JS_Av.
ANOVA $^{\mathrm{a}}$

\begin{tabular}{|r|r|r|r|r|r|}
\hline Mod. & Sm of Sq. & $<\mathrm{df}>$ & Mn Sq. & $<\mathrm{F}>$ & $<$ Sig. $>$ \\
\hline Reg. & 1689.525 & 1 & 1689.525 & 68.001 & $.000^{\mathrm{b}}$ \\
Resi. & 18460.346 & 743 & 24.846 & & \\
Total & 20149.871 & 744 & & & \\
\hline
\end{tabular}

a. Dep. Var: OC_Av.

b. Predict: (Const.), JS_Av.

Coeff. $^{\text {a }}$

\begin{tabular}{|c|r|r|c|r|r|}
\hline \multirow{2}{*}{ Mod. } & \multicolumn{2}{|c|}{ Unstnd. Coef. } & \multicolumn{1}{c|}{$\begin{array}{c}\text { St. } \\
\text { Coef. }\end{array}$} & $<\mathrm{t}>$ & $<$ Sig.> \\
\cline { 2 - 4 } & \multicolumn{1}{|c|}{ B } & St. Err. & \multicolumn{1}{c|}{ B } & & \\
\hline (Const.) & 32.649 & 1.384 & & 23.593 & .000 \\
JS_Av. & .318 & .039 & .290 & 8.246 & .000 \\
\hline
\end{tabular}

a. Dep. Var: OC_Av.

\section{INTERPRETATION}

Multiple regression analysis was used to test if the job satisfaction considerably displays the participants' commitment towards their organization. The outcome of the regression point toward two outcomes which showed $29 \%$ of the var. $(\mathrm{R} 2=8.3 \mathrm{~F}(1,743)=68.001, \mathrm{p}<.005)$. Extraversion considerably shows the aggressive tendencies $(\beta=.290$, $\mathrm{p}<.005)$.

H2 : There is not a considerable effect of self efficacy on work satisfaction.

Mod. summing up

\begin{tabular}{|l|r|r|r|r|}
\hline Mod. & \multicolumn{1}{|c|}{$\mathrm{R}$} & \multicolumn{1}{|c|}{ R Sq. } & Adjst. R Sq. & $\begin{array}{c}\text { Std. Error of } \\
\text { Estmt. }\end{array}$ \\
\hline 1 & $.099^{\mathrm{a}}$ & .010 & .008 & 4.72394 \\
\hline
\end{tabular}

a. Predict: (Const.), SE_Av.

ANOVA $^{\mathrm{a}}$

\begin{tabular}{|c|r|r|r|r|r|}
\hline Mod. & Sm of Sq. & $<\mathrm{df}>$ & Mn. Sq. & $<\mathrm{F}>$ & $<$ Sig. $>$ \\
\hline Reg. & 162.806 & 1 & 162.806 & 7.296 & $.007^{\mathrm{b}}$ \\
Resi. & 16580.529 & 743 & 22.316 & & \\
Tot. & 16743.334 & 744 & & & \\
\hline
\end{tabular}

a. Dep. Var: JS_Av.

b. Predict: (Const.), SE_Av.

Coeff. $^{\mathrm{a}}$

\begin{tabular}{|r|r|r|c|c|r|}
\hline \multicolumn{1}{|l|}{ Mod. } & \multicolumn{2}{|c|}{ Unstnd. Coef. } & \multicolumn{1}{c|}{$\begin{array}{c}\text { St. } \\
\text { Coef. }\end{array}$} & $<\mathrm{t}>$ & $<$ Sig. $>$ \\
\cline { 2 - 4 } & \multicolumn{1}{|c|}{ B } & St. Err. & B & & \\
\hline (Const.) & 39.625 & 1.497 & & 26.474 & .000 \\
SE_Av. & -.129 & .048 & -.099 & -2.701 & .007 \\
\hline
\end{tabular}

a. Dep. Var: JS_Av.

\section{INTERPRETATION}

Multiple regression analysis performed to check if the efficacy significantly exhibits the respondent's job satisfaction. The outcome of regression point toward the two predictors explained $9.9 \%$ of the var. 


\section{On Associative Meanings of Medicinal Traditional Fruits: A Semantico-Pragmatic Perspective of Local-Cultured Environmental Richness}

$(\mathrm{R} 2=0.8 \mathrm{~F}(1,743)=7.296, \mathrm{p}>005)$. Extraversion did not considerably exhibited the aggressive propensity $(\beta=-.099$, $p$ $>005)$.

H3: There is a considerable effect of self efficacy on organizational commitment.

Mod. summing up

\begin{tabular}{|l|r|r|r|r|}
\hline Mod. & \multicolumn{1}{|c|}{$\mathrm{R}$} & \multicolumn{1}{|c|}{ R Sq. } & Adjst. R Sq. & $\begin{array}{c}\text { Std. Error of } \\
\text { the Estmt. }\end{array}$ \\
\hline 1 & $.300^{\mathrm{a}}$ & .090 & .089 & 4.96802 \\
\hline
\end{tabular}

a. Predict: (Const.), SE_Av.

ANOVA $^{\mathrm{a}}$

\begin{tabular}{|c|r|r|r|r|r|}
\hline Mod. & Sm of Sq. & $<\mathrm{df}>$ & Mn. Sq. & $<\mathrm{F}>$ & $<$ Sig. $>$ \\
\hline Reg. & 1811.709 & 1 & 1811.709 & 73.404 & $.000^{\mathrm{b}}$ \\
Resi. & 18338.162 & 743 & 24.681 & & \\
Total & 20149.871 & 744 & & & \\
\hline
\end{tabular}

a. Dep. Var: OC_Av.

b. Predict: (Const.), SE_Av.

Coeff. $^{a}$

\begin{tabular}{|c|c|c|c|c|c|}
\hline \multirow[t]{2}{*}{ Mod. } & \multicolumn{2}{|c|}{ Unstd. Coeff. } & Stnd. & \multirow[t]{2}{*}{$\mathrm{t}$} & \multirow[t]{2}{*}{ Sig. } \\
\hline & B & $\begin{array}{l}\text { Std. } \\
\text { Error }\end{array}$ & Beta & & \\
\hline (Const.) & 30.565 & 1.574 & & 19.418 & .000 \\
\hline SE_Av. & .430 & .050 & .300 & 8.568 & .000 \\
\hline
\end{tabular}

a. Dep. Var: OC_Av.

\section{INTERPRETATION}

Multiple regression analysis was done to examine if the efficacy considerably envisaged the respondent's organizational commitment. Outcome of the regression analysis point out the two predictors explained $30 \%$ of the var. $(\mathrm{R} 2=0.89 \mathrm{~F}(1,743)=73.404, \mathrm{p}<005)$. Extraversion considerably envisaged aggressive propensity $(\beta=-.300, p$ $<005)$.

H4: There exists a considerable effect of self efficacy and work satisfaction on institutional commitment.

Mod. Summary

\begin{tabular}{|l|r|r|r|r|}
\hline Mod. & \multicolumn{1}{|c|}{$\mathrm{R}$} & \multicolumn{1}{|c|}{ R Sq. } & Adjst. R Sq. & $\begin{array}{c}\text { Std. Error of } \\
\text { the Estmt. }\end{array}$ \\
\hline 1 & $.439^{\mathrm{a}}$ & .193 & .191 & 4.68205 \\
\hline
\end{tabular}

a. Predict: (Const.), JS_AVG, SE_AVG

ANOVA $^{\mathrm{a}}$

\begin{tabular}{|c|r|r|r|r|r|}
\hline Mod. & Sm of Sq. & $<$ df $>$ & Mn. Sq. & $<$ F $>$ & $<$ Sig. $>$ \\
\hline Reg. & 3884.041 & 2 & 1942.020 & 88.589 & $.000^{\mathrm{b}}$ \\
Resi. & 16265.830 & 742 & 21.922 & & \\
Total & 20149.871 & 744 & & & \\
\hline
\end{tabular}

a. Dep. Var.: OC_Av.

b. Predict: (Const.), JS_Av., SE_Av.

\begin{tabular}{|r|r|r|c|r|r|}
\hline \multirow{2}{*}{ Mod. } & \multicolumn{2}{|c|}{ Unst. Coef. } & \multicolumn{1}{c|}{$\begin{array}{c}\text { St. } \\
\text { Coef. }\end{array}$} & $<\mathrm{t}>$ & $<$ Sig. $>$ \\
\cline { 2 - 4 } & \multicolumn{1}{|c|}{ B } & St. Err. & \multicolumn{1}{c|}{ B } & & \\
\hline (Const.) & 16.557 & 2.068 & & 8.006 & .000 \\
SE_Av. & .476 & .048 & .332 & 10.005 & .000 \\
JS_Av. & .354 & .036 & .322 & 9.723 & .000 \\
\hline
\end{tabular}

a. Dep. Var: OC_Av.

\section{INTERPRETATION}

Multiple regression analysis was used to test if the self efficacy and job satisfaction significantly predicted participants' organizational commitment. The outcome of regression point to the 2 predictors that elucidated $43.9 \%$ of the var. $\left(\mathrm{R}^{2}=0.191 \mathrm{~F}(2,742)=88.589\right.$, $\left.\mathrm{p}<005\right)$. Therefore, the extraversion considerably exhibited aggressive tendencies $(\beta=-.332, \mathrm{p}<005)$.

\section{CONCLUSION}

1. It was found that job satisfaction significantly impact organisational commitment. For testing this multiple regression analysis was used and it shows a highly affirmative association between the two factors. Therefore, it can be inferred that job satisfaction effects teacher's organisational commitment.

2. It is stated that there is an insignificant effect of self efficacy on work satisfaction. For testing this multiple regression analysis was used and it does not show affirmative association between the two factors. So we can say that there exists no important relationship between job satisfaction and self efficacy of the university teachers.

3. After this regression was used to test the association between self efficacy and organisational commitment. The results show positive association between the two. So it can be said that self efficacy significantly impact institutional commitment.

4. The reg. analysis conducted to test the connection between work satisfaction, self efficacy and institutional commitment showed positive results. Therefore, job satisfaction and self efficacy significantly impact organisational commitment of the university teachers.

5. So we can say that teacher's satisfaction at workplace is greatly influenced by some factors which include job satisfaction organisational commitment and self efficacy. These factors have a significant positive impact among themselves. So we should focus on these three factors in order to improve teachers' satisfaction at workplace.

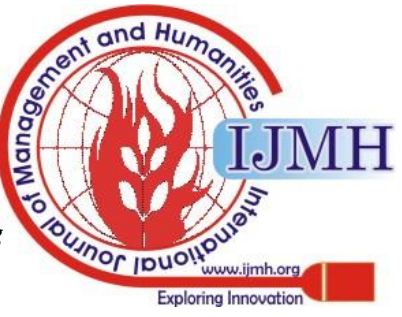




\section{REFERENCES}

1. Aamodt, M. G. (2007). Industrial/Organizational Psychology: An Applied Approach. Belmont, CA: Thomson Learning.

2. Adams J. S. (1963). Towards an understanding of inequity. J. Abnorm. Soc. Psychol. 67:422.

3. Akhtar, Saleem et al (2012), Self-efficacy and optimism as predictors of organizational commitment among bank employees, International Journal of Research Studies in Psychology.

4. Brooke, P. P., Russell, D. W., Jr., \& Price, J. L. (1988). Discriminant validation of measures of job satisfaction, job involvement, and organizational commitment. Journal of Applied Psychology, 73(2), 139-145. doi 10.1037/0021-9010.73.2.139

5. Brown, D., \& Sargeant, M. A. (2007). Job satisfaction, organizational commitment, and religious commitment of full-time university employees. Journal of Research on Christian Education, 16(2), 211-241.

6. Bull, I. H. F. (2005). The relationship between job satisfaction and organisational commitment amongst high school teachers in disadvantaged areas in the Western Cape (Doctoral dissertation, University of the Western Cape).

7. Cranny, C., Smith, P., \& Stone, E. (1992). Job satisfaction: how people feel about their jobs and how it affects their performance. New York: Lexington.

8. Canrinus, E. T., Helms-Lorenz, M., Beijaard, D., Buitink, J., \& Hofman, A. (2012). Self-efficacy, job satisfaction, motivation and commitment: Exploring the relationships between indicators of teachers' professional identity. European journal of psychology of education, 27(1), 115-132.

9. Cooper-Hakim, A., \& Viswesvaran, C. (2005). The construct of work commitment: Testing an integrative framework. Psychological bulletin, 131(2), 241.

10. Day, C., Fernandez, A., Hauge, T. E., \& Muller, J. (2005). Stories of change and professional development. In The life and work of teachers (pp. 113-132). Routledge.

11. De Witte, H., \& Buitendach, J. H. (2005). Job insecurity, extrinsic and intrinsic job satisfaction and affective organisational commitment of maintenance workers in a parastatal. South African Journal of Business Management, 36(2), 27-37.

12. Eichinger, J. (2000). Job stress and satisfaction among special education teachers: Effects of gender and social role orientation. International journal of disability, development and education, 47(4), 397-412.

13. Fox, S., Spector, P. E., Goh, A., Bruursema, K., \& Kessler, S. R. (2009). The deviant citizen: Clarifying the measurement of organizational citizenship behavior and its relation to counterproductive work behavior. Loyola University Chicago.

14. Getahun, T., Tefera, B. F., \& Burichew, A. H. (2016). Teacher's Job Satisfaction And Its Relationship With Organizational Commitment In Ethiopian Primary Schools: Focus On Primary Schools Of Bonga Town. European Scientific Journal, 12(13).

15. Giose, W. C. J. (2004). Perceptions of educare teachers regarding the effects of disadvantagement on the psychosocial development of historically disadvantaged preschool children.

16. Judge, T. A., Bono, J. E., \& Locke, E. A. (2000). Personality and job satisfaction: The mediating role of job characteristics. Journal of applied psychology, 85(2), 237.

17. Klein, H. J., Molloy, J. C., \& Cooper, J. C. (2009). Conceptual foundations: construct definitions and theoretical representations of workplace commitments. In H. J. Klein, T. E. Becker, \& J. P. Meyer (Orgs.), Commitment in organizations: accumulated wisdom and new directions (pp. 3-36). New York: Routledge Academic.

18. Lawrence, A., \& Lawrence, P. (2009). Values congruence and organisational commitment: $\mathrm{P}-\mathrm{O}$ fit in higher education institutions. Journal of Academic Ethics, 7(4), 297-314.
19. Meyer, J. P., Stanley, D. J., Herscovitch, L., \& Topolnytsky, L. (2002). Affective, continuance, and normative commitment to the organization: A meta-analysis of antecedents, correlates, and consequences. Journal of vocational behavior, 61(1), 20-52.

20. Morrison, R. L. (2008). Negative relationships in the workplace: Associations with organisational commitment, cohesion, job satisfaction and intention to turnover. Journal of Management \& Organization, 14(4), 330-344.

21. Nagar, K. (2012). Organizational commitment and job satisfaction among teachers during times of burnout. Vikalpa, 37(2), 43-60.

22. Park, S., Henkin, A. B., \& Egley, R. (2005). Teacher team commitment, teamwork and trust: Exploring associations. Journal of educational administration, 43(5), 462-479.

23. Park, S., Henkin, A. B., \& Egley, R. (2005). Teacher team commitment, teamwork and trust: Exploring associations. Journal of educational administration, 43(5), 462-479.

24. Robbins, S. P., \& Judge, T. A. (2009). Organizational Behavior. Pearson Prentice Hall.

25. Shah, N. H., \& Jumani, N. B. (2015). Relationship of job satisfaction and turnover intention of private secondary school teachers. Mediterranean Journal of Social Sciences, 6(4), 313.

26. Shann, M. H. (1998). Professional commitment and satisfaction among teachers in urban middle schools. The Journal of Educational Research, 92(2), 67-73.

27. Türkoğlu, M. E., Cansoy, R., \& Parlar, H. (2017). Examining relationship between teachers' self-efficacy and job satisfaction. Universal Journal of Educational Research, 5(5), 765-772

28. Wu, T. F., Tsai, M. H., Fey, Y. H., \& Wu, R. T. (2006). A study of the relationship between manager's leadership style and organizational commitment in Taiwan's international tourist hotels. Asian Journal of Management and Humanity Sciences, 1(3), 434-452.

29. Yang F.-H., Chang C.-C. (2008). Emotional labour, job satisfaction and organizational commitment amongst clinical nurses: a questionnaire survey. Int. J. Nurs. Stud. 45, 879-887. 10.1016/j.ijnurstu.2007.02.001

30. Zadeh, M. H., Esmaili, M. R., Tojari, F., \& Zarei, A. (2015). Relationship between job satisfaction, organizational commitment and organizational justice with organizational citizenship behavior in physical educators. MAGNTResearch Report, 3(2), 199-210.

31. Zaini Jamaludin (2009) Perceived Organizational Justice And Its Impact To The Development Of Commitments: A Regression Analysis, World Journal of Management Vol.1 No.1 Pp. 49-61.

\section{AUTHOR'S PROFILE}

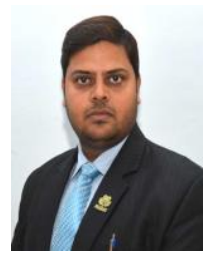

Mr. Pragalbh Sharma, is working as Assistan Professor in the Department of Management, Institute of Business Management, GLA University, Mathura (UP)-India. He has done his MBA in Human Resource and Information Technology in 2008 from UP Technical University, Lucknow. He is into teaching since 2008 and has an interest in teaching Human Resource, Organisational Behaviour, Negitiation and Counseling, Labour Laws, Database Management System, Management Information System etc. He has guided more than 50 undergraduate research projects till now and has participated and presented papers in more than 20 workshops and conferences of repute. 


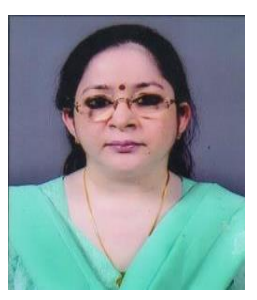

Professor Aparna Raj, is a Professor in the Department of Tourism and Hotel Management in Bundelkhand University, Jhansi (UP)-India. She has done her MBA from Bundelkhand University in 1988 and received her doctorate degree in 1992 from Bundelkhand University, Jhansi. She is having her specialization in Organisational Behaviour, Human Resource Management, Training \& Development, Strategic Management, Tourist Behaviour \& Communication Skills. She has a very rich teaching experience of more than 28 years. She has guided $10 \mathrm{Ph}$.D. scholars on their doctoral studies till now. She has also conducted several training programs and undertaken several significant projects.

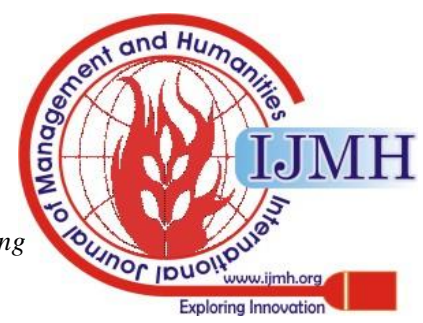

